\title{
In the Wake of Charles Darwin and Beyond: A Tribute to Ernst Mayr
}

\author{
J. Haffer: Ornithology, Evolution, and Philosophy. The Life and Science of Ernst Mayr \\ 1904-2005. Springer-Verlag, Berlin Heidelberg, 2007, 464 pp, \$ 119, 00
}

\section{U. Kutschera}

Published online: 21 November 2009

(C) Springer Science + Business Media, LLC 2009

In April 1860, the zoologist Ernst Haeckel (1834-1919) came back to Berlin from an extended trip to Italy. Only a few days after his arrival, he was informed by his colleagues that during his stay abroad a "strange book of a crazy Englishman" had been published in which all concepts concerning the origin of species are turned upside down. At weekly meetings of the Gesellschaft Naturforschender Freunde zu Berlin $(G N F)$ - an association of naturalists that still exists today-Darwin's monograph was hotly debated. The majority of Berlin's famous university professors agreed that Darwin's theory of descent with modification (summarized in 1860 under the term "Darwinism") is an "unfounded speculation;" moreover, they argued that "in a few years from now nobody will discuss this "British nonsense' any more." The 26-year-old Haeckel was unimpressed by this harsh verdict: after he had read Darwin's book On the Origin of Species (1859) in an excited mood, he was entirely convinced by this novel theory and became a life-long defender, supplementer, and popularizer of Darwinism (H. Schmidt, Ernst Haeckel. Leben und Werke, Berlin 1926).

In February 1904, "Germany's Darwin of the nineteenth century," as Haeckel was called, celebrated his 70th birthday. Five months later, Ernst Mayr was born in Kempten (Bavaria, Germany). Both Ernsts were enthusiastic naturalists. They first studied medicine at the University of Berlin, where they joined the GNF. Then they made the switch to systematic zoology and became world leaders in

\section{U. Kutschera $(\bowtie)$}

Institute of Biology, University of Kassel,

Heinrich-Plett-Strasse 40,

34109 Kassel, Germany

e-mail: kut@uni-kassel.de their respective fields: Haeckel as an invertebrate zoologist (Radiolarians, Sponges etc.), Mayr as an ornithologist. They discovered/described many new animal species and published (or edited) important zoological monographs (E. Haeckel: Die Radiolarien, Berlin 1862, 1877; E. Mayr et al.: Check-list of the Birds of the World, 1960-1986). The older Ernst became the most prominent biology professor of Jena, where his private museum - the Ernst HaeckelHaus - is now part of the University. Mayr emigrated in 1931 to the United States, where he held the position of Alexander Agassiz Professor of Zoology at Harvard University from 1953 until his death (2005). Harvard's Ernst Mayr Library is named in his honor.

Haeckel published his most important book at the age of 32 (Generelle Morphologie der Organismen, Berlin 1866); Mayr was 38 years old when his masterpiece Systematics and the Origin of Species (New York, 1942) appeared in print. Both monographs were written under the influence of Darwin's work of 1859 and led to a considerable refinement and extension of classical Darwinism. In Haeckel's book of 1866 two new areas of research, phylogenetics and evolutionary embryology, were founded; Mayr's monograph of 1942 became one of the cornerstones of the Synthetic theory of Biological Evolution. Both Haeckel and Mayr started their careers as specialists, but later evolved, under the influence of "Darwin 1859," into generalists of biology. They published important books on evolution as well as various philosophical aspects of the biological sciences (Fig. 1).

However, significant differences in their later writings are apparent. Haeckel's biophilosophy (Die Welträtsel, Berlin 1899; Die Lebenswunder, Stuttgart 1904; Die Kristallseelen, Jena 1917) developed under the label "Monism" into a pseudo-religious system of thought, whereas Mayr's corresponding works - exemplified in his splendid monographs The Growth of Biological Thought, Toward a New 
Philosophy of Biology and his last opus What Makes Biology Unique? (Cambridge, 1982, 1988, and 2004) are free of any non-naturalistic or ideological excursions.

Since Haeckel's time up to the present, numerous books on the life and work of this eminent scientist have been published. Jürgen Haffer opens his biography of Ernst Mayr with an overview of his elegant, comprehensive work: the ornithologist, evolutionist and historian/philosopher of biology is described in detail. In one of the book's 12 chapters the author outlines Mayr's collaboration with the Russian/ American naturalist and geneticist Theodosius Dobzhansky (1900-1975). Based on a series of as yet unpublished letters, we learn under which circumstances two of the most influential "post-Darwin -books dealing with the mechanisms of evolution, Dobzhansky's Genetics and the Origin of Species of 1937 and Mayr's corresponding work of 1942 quoted above, originated. Moreover, Ernst Mayr's most important contributions to the development of our modern view of what species are and are not as well as the modes of speciation in animal populations are discussed at length in this biography. A list of all scientific publications of Mayr (856 works, inclusive of 21 books) supplements Haffer's monograph, which will become a classic in the literature on the history of twentieth century biology.
Fig. 1 The ornithologist Ernst Mayr (1904-2005) surrounded by Haeckel's drawing of birds

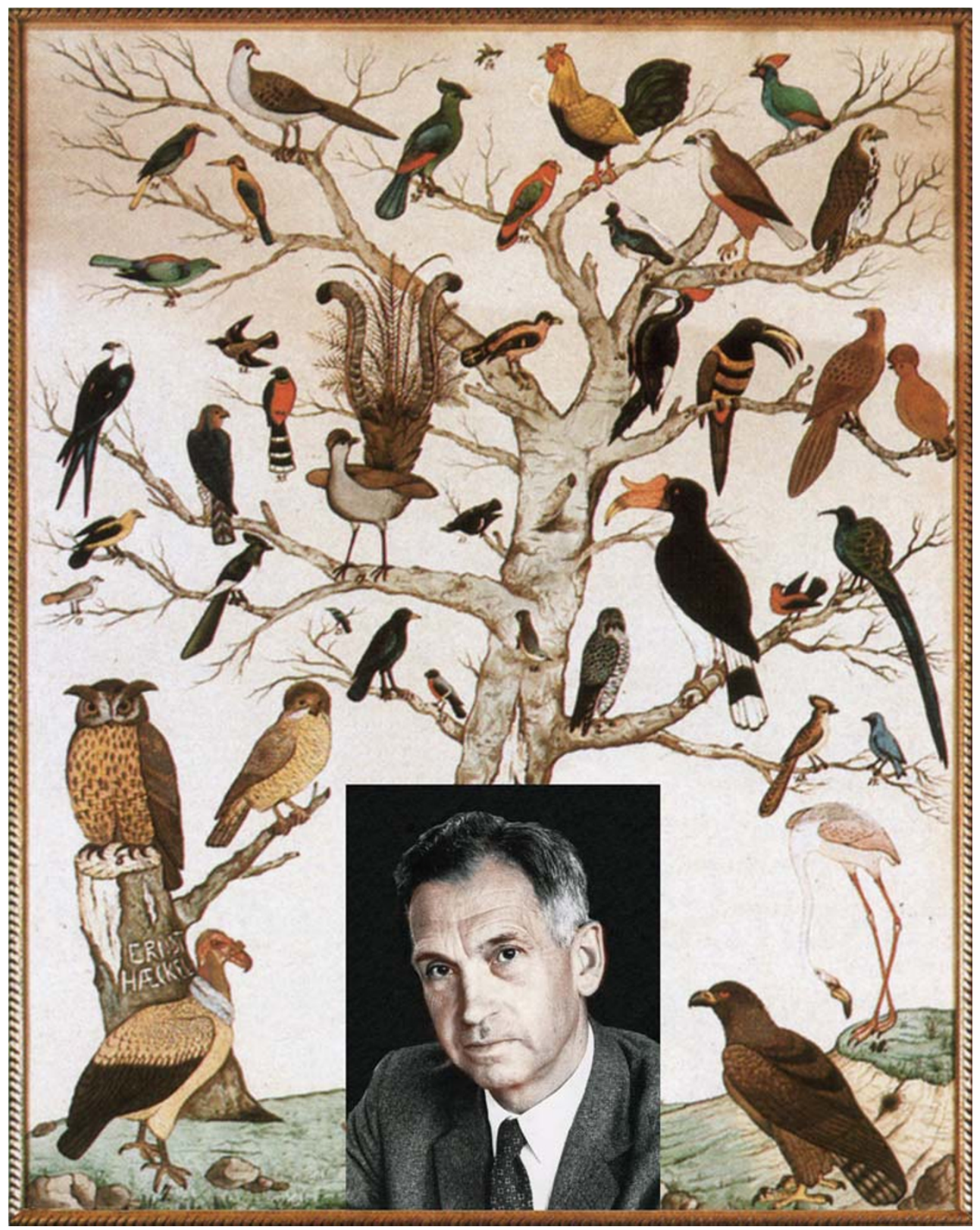


Ernst Mayr died in the "Einstein year," 2005. Haffer's book documents in detail that Mayr-America's "Darwin of the twentieth century" - was one of the most influential biologists of his time. Alfred Russel Wallace once called Charles Darwin the "Newton of biology." After reading Haffer's comprehensive biography, we have to conclude that Ernst Mayr may be regarded as the "Einstein of the modern life sciences." This first biography, which contains many unpublished photographs such as a picture showing "the three Mayr brothers in Kempten (Allgäu, Bavaria), August 1907," will certainly open a series of books on Ernst Mayr and his outstanding scientific achievements. 